\title{
Assistance of Indigofera Cultivation as Batik Natural Dyes in Kampung Alam Malon, Gunungpati Semarang
}

\author{
Ning Setiati, Ely Rudyatmi, Krispinus Kedatipukan, Dyah Rini Indriyanti \\ Departement of Biology, Faculty of Mathematcs and Natural Science, \\ Universitas Negeri Semarang \\ ningsetiati@mail.unnes.ac.id
}

Received: $10^{\text {th }}$ May $2020 \mid$ Accepted: $1^{\text {st }}$ December 2020 | Published: $30^{\text {th }}$ January 2021

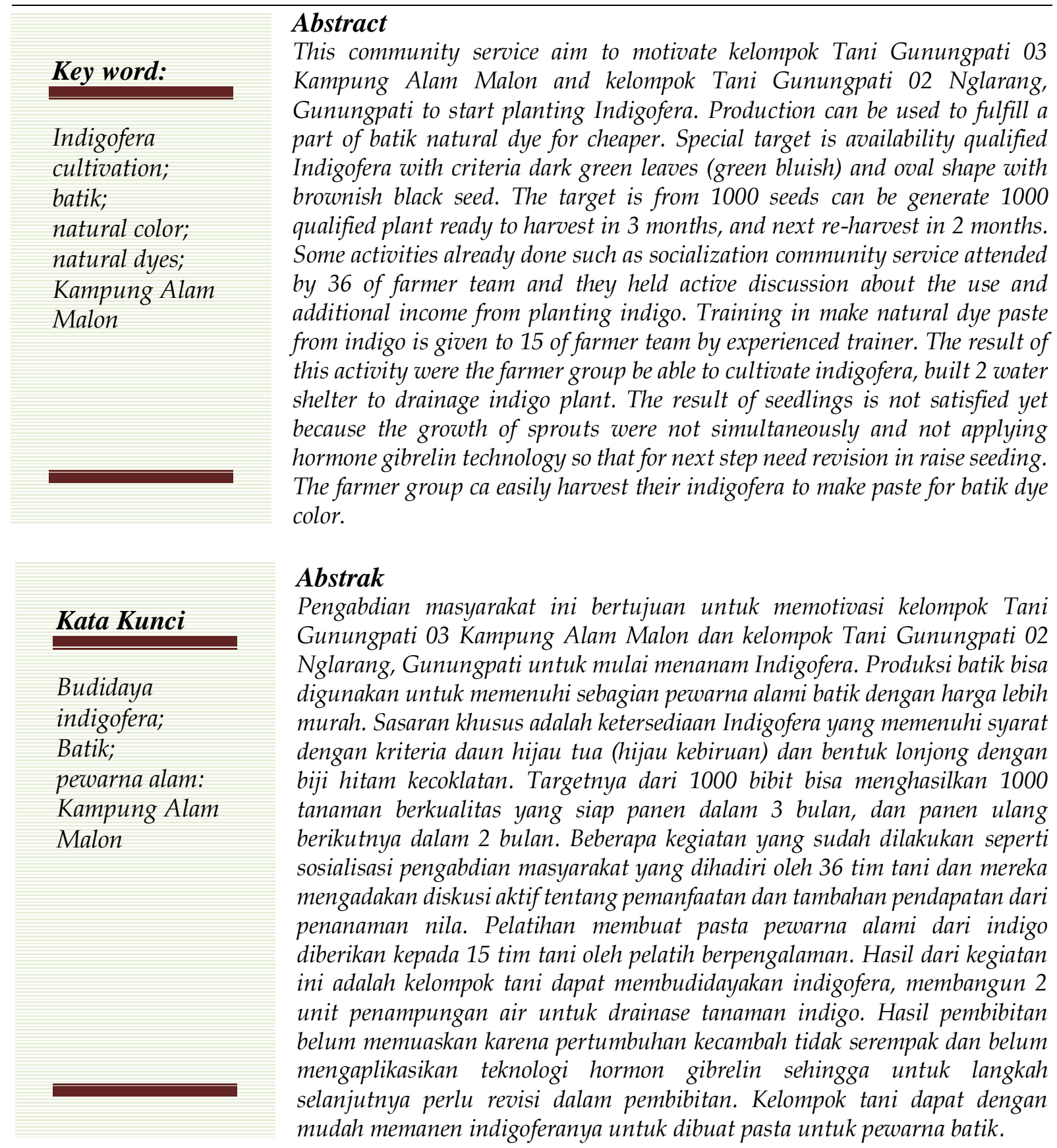




\section{INTRODUCTION}

Kampung Alam Malon as a batik center with natural color, a natural tourism village, a center for cultural and religious activities as a thematic village in Semarang. Kampung Alam Malon is a complete enough village with a vast expanse of rice fields, cattle, broilers and laying hens, cattle that are ready to squeeze, small industries ready for export charcoal and durian gardens that are ready for harvest. For visitors who want to learn creating batik with materials derived from nature, can learn to create batik using natural colors, including indigofera plants. In Kampung Alam Malon there are two studios and two batik boutique namely Zie Batik Mangrove and Salma Batik. In making batik, colouring become one of the important elements to create beautiful batik artwork. Batik natural dyes include Indigo plant as one of the choices to produce the blue color of classic batik naturally (Setiati et al., 2020).

To fullfill the needs of natural colors is still an obstacle for batik craftsmen in Kampung Alam Malon, so the natural dyes used by batik craftmen are still imported from outside Kelurahan Gunungpati. Indigo Farmer Group in Kampung Alam Malon, chaired by Samsul Muarif and its 35 members did not plant indigofera because they had bad experience. They failure to obtain qualified crop production due to lack of capital and knowledge. Farmer groups need assistance from business equipment and to raise the spirit of qualified indigofera cultivation (Theresia et al., 2020).

This plant is easy to be cultivated and can grow well up to a height of $1200 \mathrm{~m}$ above sea level, easy produces seeds so it is easy to be propagated, resistant to drought, has deep roots and can maintain fertility so it is suitable for land conservation, quick harvested since planting only 3 months (Morip et al., 2020). To supply qualified seeds, science and technology (IPTEK) are needed to produce good quality indigofera.

Traditional planting is very minimal production inputs, for example with improvised soil management, local seedlings, planting techniques to follow its predecessors, the use of improvised fertilizers and even without fertilization, maintenance is not serious, of course this must be abandoned and must be changed towards modern who are able to compete in producing quality and quantity in terms of harvest value (Muzayyinah, 2014). Quality crop maintenance must be supported by environmental friendly fertilization techniques, in the sense that chemical fertilizers must be minimized and should use predominantly in organic or organic fertilizers.

The problem of partners is prioritized on the failure production of indigofera so 
that it cannot fullfill the needs of natural color for batik craftsmen. Failure is caused due to lack of knowledge on how to process planting media (soil) and the use of fertilizers so that the soil can be used sustainably, lack of water drainage to treat plant growth, poor seed quality and lack of availability of qualified fertilizers (Ranti et al., 2019). Such conditions were mutually agreed between the partners and the service team to be overcome by providing qualified seeds, environment friendly fertilizer, repairing waterways near the river and improving maintenance management.

There are an area of $9400 \mathrm{~m} 2$ which has potential to be planted has not been used optimally for the production of qualified indigofera in Gunungpati. Based on the need for raw materials for natural batik dyes, farmer group of Gunungpati 03 will work together with Semarang State University (Universitas Negeri Semarang/Unnes) community service team to grow indigofera. The results of observations and discussions based on the potential and enthusiasm of indigofera farmer groups require around 1000 seedlings to be planted in an excrooked land area of $9400 \mathrm{~m} 2$.

Justification of priority issues agreed between the service team and partners accompanied by the local Agriculture Office to be resolved immediately during $\mathrm{IbM}$ activities are:

1. Help improve the welfare of members and farmers' income,

2. Provide employment opportunities for the surrounding community,

3. Add entrepreneurial spirit to the surrounding community,

4. Introduce professional management in groups.

\section{METHODS}

Partner's problem is fail to obtain qualified crop production due to lack of capital and knowledge. Farmer groups need help from business equipment and assistance to raise the spirit of indigofera cultivation. Ex-bent land area in 9400 m2 which has potential to be planted has not been used optimally for production of qualified indigofera.

The solution offered by Unnes community service team to work together to overcome priority problems of partners in achieving target is Science and Technology for Gunungpati 3 Farmers team in Kelurahan Gunungpati which is implemented in form of indigofera cultivation to produce qualified natural batik plants with notice to various things, namely:

a. Growing requirements

Indigofera can grow from 0 meters to $1,650 \mathrm{~m}$ above sea level, and thrive in 
loose soil that is rich in organic matter. As a dye-producing plant, indigofera is planted in the highlands and as a secondary crop in paddy fields. Land should be well-designed enough.

b. Plants Propagation

Indigofera development is by seed, except Indigofera suffruticosa which can be cultured by cuttings. To prevent damage by insects, seeds can be treated with kitchen ash before sowing. Indigofera arrecta seeds have hard skin and need to be filed. It can be propagated with indigo cuttings which are used are the branches with the best growth, especially on land which already producing. Cutting needs to be done with a sharp knife and to avoid bruising/tearing, then at the time of cutting into plant material/cuttings whose length is $+30 \mathrm{~cm}$. Material cut by hand, the cuttings are not immediately planted but bound and left for 1 to 3 days of cool/shady place with tip of cuttings placed above. After the cutting surface is dry, then the cuttings can be planted in field.

c. Plantation

After the land/moor once or several times plowed or digged, indigofera cuttings are planted with space between $60 \mathrm{~cm}$ in a row of $60-90 \mathrm{~cm}$, for others indigofera 45-60 cm. To drain rainwater every 360 $\mathrm{cm}$ in space channel is made drainage for water drainage. If planting with seeds can be directly planted in field, each hole is filled with 3 or 4 seeds, another way to make a nursery first. Germination in nurseries takes 4 days. If the nursery is used, seedlings can be transplanted to plantations at 4-6 weeks. While planting in field with cuttings of 2-3 cuttings per hole. After 2 weeks, the buds coming out from cuttings began to appear.

d. Maintenance

After 1 month old and looks fresh green, weaving and weeding can be done, at the same time the rows are put together. One month later the second weeding and the soil is made loose and the rows are reburied so that there is higher mounds. At the end of 4 months or the beginning of 5 months after the plants cover the soil, it's time to cut. In general, this time falls with a lot of flowering. As ground cover plants the stems are cut in regular intervals.

e. Eradication of pests and diseases: Indigofera arrecta can be attacked by Bacillus solanaceaarum. In Java Indigofera tinctoria is not susceptible to pests and diseases, but after lignification occurs in humid regions, this species can be attacked by various types of fungi and insects, by the nematode Heterodera glycines. 


\section{f. Harvest}

When indigofera leaves color is dark green evenly begin to wilt and begin to turn yellow, the indigofera results will be less. How to determine harvest time is indeed difficult. Based on the experienced, farmers determine harvest time based on leaf color and leaf odor when it squeezed. Tree branches are harvested, usually in the morning, when plants are 4-5 months old and have formed dense stands and it is usually a flowering stage. After 3-4 months later the plants can be cut again; Plants can be harvested 3 times a year. The life span of plants as dyes is 2-3 years, and 1.5-2 years as ground cover. It can only be harvested once if planted in the fields, because these plants must make room for the next rice plant.

Work procedures to support the realization of offered solutions to solve problems are:

1. Arrange permit letter to Kelurahan Gunungpati Office

2. Socialization of PKM activities to 35 indigofera farmer team of Gunungpati 03, was attended by agricultural officers

3. Cultivating ex-crooked land, and soil fertilization,

4. Facilities and infrastructure for indigofera planting (agricultural equipment)
5. Procurement of 1000 seedlings of indigofera

6. Seeds are planted in polybags

7. Assist the procurement of manure. For good results, administering manure in a planting hole is 250-300 g/hole. To produce a good canopy shape and good branch growth, cut the plant with a height of $75-100 \mathrm{~cm}$. The material needed to make compost from cow dung is at least $80-83 \%$ cow dung and is better when mixed with urine,s awdust or husk or straw, 10\% charcoal, 2\% agricultural lime and $0.25 \%$ EM4 microorganic. Step to make manure is after all the ingredients are available, it's time to do the composting steps.

a. Mix all ingredients needed to make compost, cow dung, sawdust, ash and lime, mix well then stack in a place protected from direct sunlight and rain (Better if it is piled up in a special compost making place. Leave it for 1 day). The next day stirring a pile of compost, then sprinkle with EM4, stir until distributed, then stack again with minimum height $80 \mathrm{~cm}$.

b. Leave the stack open for up to 7 days, but it must be maintained to avoid heat and rain. On the 7 th day, turn over the pile so that the oxygen supply can enter the material. Oxygen is needed for microbial 
activity. Reversal of material is done every 7 days. Microbial activity can be characterized by an increase in temperature. Usually an increase in temperature occurs before the 8th day until the 21st day. On the 28th day the temperature will decrease again. The temperature rise can occur up to 300oC. This high temperature will make the compost become sterile from weed seeds and pathogenic bacteria. The mixture of cow dung has become compost if the temperature is neutral and the color is brownish black.

8. Procurement of water shelter and pipe for watering. A $500 \mathrm{~m}$ long pipe is needed to drain water from the river and then it is held in 2 water shelters, especially for water supply during dry season.

9. Spraying anti-pest.

10. The harvesting technique is done by cutting leaves and stems. The best time to take harvest indigofera is between 4 to $6 \mathrm{am}$. However, this rule only applies to crops that aim to produce natural fabric dyes. So if the goal is different, it can be done in the afternoon.

11. Assistance in product marketing to batik craftmen in Kelurahan Gunungpati.
Partner participation in program

1. Provide ex-bent land in $9400 \mathrm{~m} 2$ wide for indigo cultivation,

2. Working together to cultivate the soil and make manure

3. Helps to find indigo seeds and

4. planted in polybags

5. Support the program cooperatively,

6. Responsible for the sustainability of the PKM program.

The output of this program are:

1. Qualified indigofera with the size of each plant are plants specifications that can produce dark green leaves (bluish green) and oval shaped with blackish brown seeds

2. Plants that are produced reach $85 \%$ of quality of 1000 planted seedling,

3. Continuity of activities in form entrepreneurial of indigofera is Rp1.400.000 a month.

\section{RESULT}

Results of activities that have been achieved training on making indigofera natural color paste. The activity began with a training on making pasta to 16 members of Gunungpati 03 Farmer group by presenting instructors. In training activities the participants were given a theoretical explanation and a description of commercial 
benefits to each member if they had skill to make indigo paste.

The training was complemented with direct practice carried out by participants start from harvesting, soaking for 2 nights then being given chalk. Stirring continuously until thickens, the result of making color paste obtained is blue. The blue color obtained depends on the density of the leaves plant, in dry season it will provide a more durable blue color (based on craftsmen's experience). The next activity is how to harvest indigofera in garden of Gunungpati 03 farmer group accompanied by group leader and guided by the team of community service. The technique used is trim the shoot using a knife. The purpose of this method is the cut off plant can grow back, so the next growth can be harvested up to 3 times. This activity was attended by 18 farmer who were enthusiastic to join indigofera garden and practice harvesting even it was raining.

These activities are the series of motivational activities for participants to try become professional indigofera farmers. The problem is the source of water for watering plants that is still depend on rainy season, so in dry season many plants die. The community service team and members of farmer group worked together to build water shelter in two areas around the garden.
Subsequently, the service team sought Indigofera seeds to be sown, facilitated by the materials needed for growth treatments, namely 300 polybags, planting media and gauze. Another series of activities that have been achieved up to July are the Dedication Team inviting the group leader and all members to a meeting at the chairman's house, Samsul. The meeting was attended by 30 participants with an evaluation agenda of the previous activity which was training on making pasta, how to harvest indigo plants and building a tando tub.

Based on members' input that concrete benefits gained as additional income have never been experienced, therefore the end of the activity begs to be realized. The training can be continued according to the service team agenda, members of farmer groups are ready to support and help and work together to realize the goal of service that is to provide quality indigo plants based on technology in ex-crooked land in Gunungpati Village, Gunungpati District.

\section{DISCUSSION}

\section{Training to Plant Indigo Seeds}

The training invited 20 group members. The training instructor is the father. Krispinus KP is one of the service team personnel. The method uses the technology of adding the hormone gribelin. The trick, seeds wrapped in water-soaked 
gauze and hormones, wait for up to 3 days and should not be exposed to sunlight, after germination is treated until the age of 6 weeks with a height of approximately 25-30 cm (Rosadi et al., 2018).

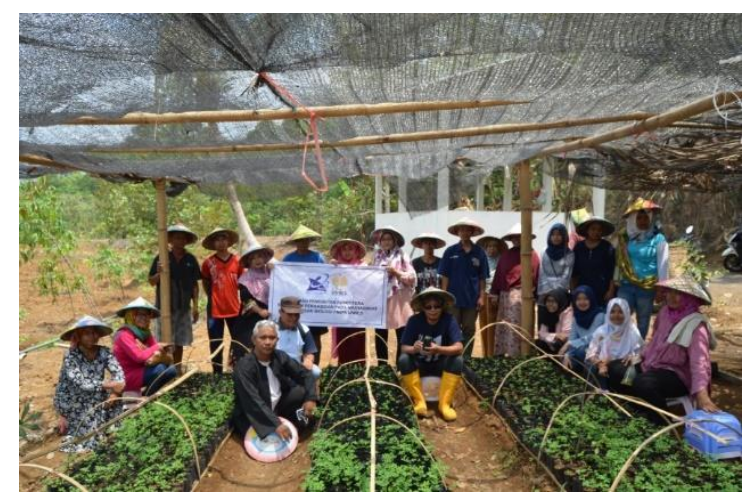

Figure 1. Training in seedling indigofera seeds

\section{Training in making manure}

Plans to invite cattle and goat farmers. The trick is the material needed to make compost from cow dung, which is cow dung at least $80-83 \%$ and is better when mixed with urine (Sindhu et al., 2016).

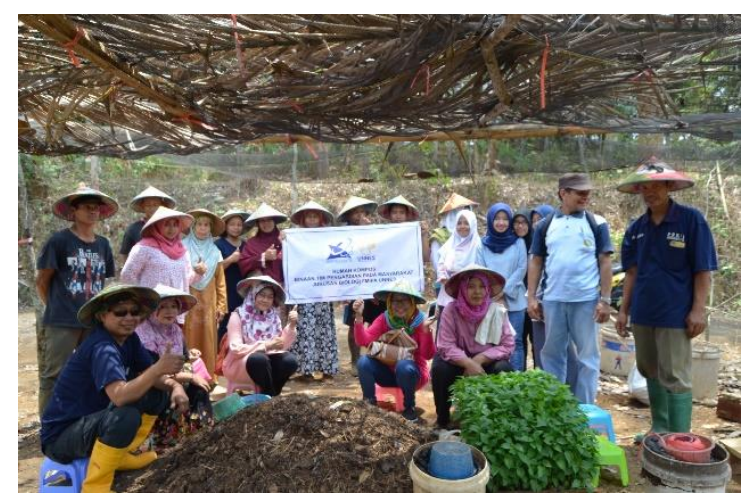

Figure 2 Practice in making manure.

Sawdust or husk or straw. $10 \%$ charcoal, 2\% agricultural lime and $0.25 \%$ EM4 microorganic ingredient (Abidin et al., 2020). How to make manure is after all the ingredients are available, it's time to do the composting steps. How to make is as below:

Mix all ingredients needed to make compost, ie cow dung, sawdust, ash and lime, evenly, then stack in a place protected from direct sunlight and rain (Better if it is piled up in a special compost making place. Leave it for 1 day). The next day stirring a pile of compost, then sprinkle with EM4, stir until evenly distributed. then stack again with a minimum height of $80 \mathrm{~cm}$. Leave the stack open for up to 7 days, but it must be maintained to avoid heat and rain. On the 7th day, turn over the pile so that the oxygen supply can enter the material evenly.

Oxygen is needed for microbial activity. The material reversal is done once every 7 days. Microbial activity can be characterized by an increase in temperature. Usually an increase in temperature occurs before the 8th day until the 21st day. On the 28th day the temperature will decrease again. The temperature rise can occur up to $300 \mathrm{oC}$. This high temperature will make the compost become sterile from weed seeds and pathogenic bacteria. The mixture of cow dung has become compost if the temperature is neutral and the color is brownish black.

\section{Drafting and loosening of ex-crooked land}

Community service is carried out by plowing the land to be planted with an area 
of $9000 \mathrm{~m} 2$ indigofera. The plan will be worked on by a number of 4 people who work as farmers. The land needed to plant indigofera plans are prepared by dividing into 5 beds, each bed can be planted with about 60 plants. Soil conditions are still dry so it needs to be watered. Indigera species can grow up to $1,650 \mathrm{~m}$ above sea level, and thrive in loose soil that is rich in organic matter.

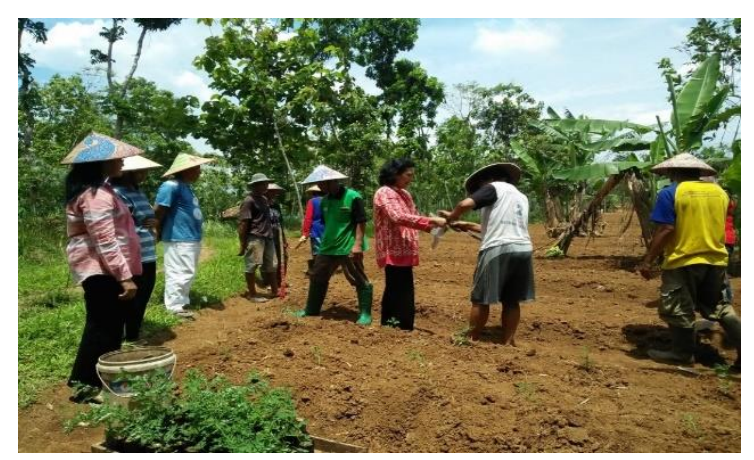

Figure 3. Preparation in planting seeds

As a dye-producing plant, indigofera is planted in the highlands and as a secondary crop in paddy soil. Land should be well drained (Ranti et al., 2019). When used as a ground cover crop, Indigofera tinctora can only be planted in gardens with little or no shade. This species enjoys a hot and humid climate with rainfall of not less than 1,750 mm / year (Telleng et al., 2016).

\section{Planting of Indigofera Seeds}

Simply use manure as the basic fertilizer. But if you want plant growth and development even faster, then use additional artificial fertilizers such as NPK, ZA,
UREA and TSP. The most practical use is NPK 15-15-15 fertilizer.

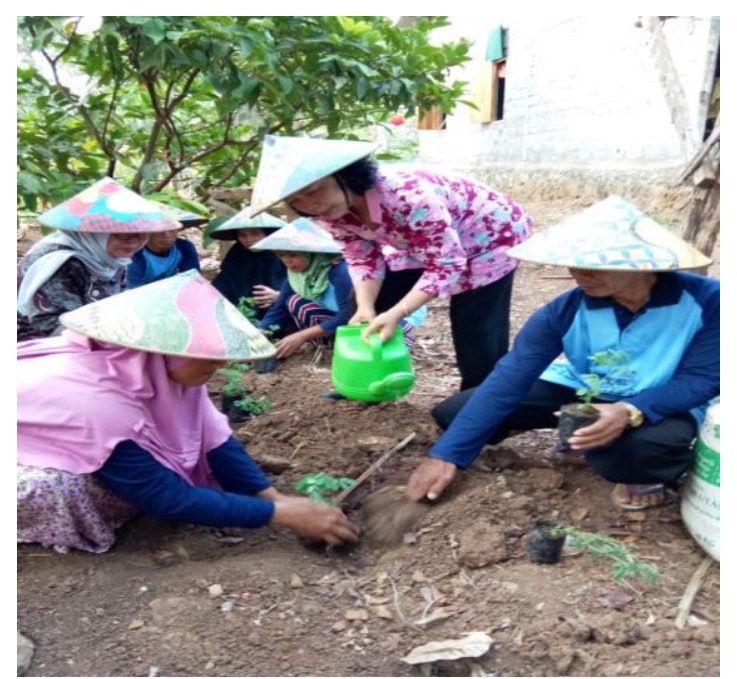

Figure 4. Training in planting indigofera

The composition of manure and NPK fertilizer is 30: 1 or can be up to 50: 1 which must be more manure (Sindhu et al., 2016). So that the results are more optimal, it can make bokashi or ferment the fertilizer first. This will make fertilizer nutrients absorbed quickly by plants, by using EM4 to make this bokashi.

\section{Harvesting of Indigofera Plants}

How to harvest Indigofera plants The next activity is how to harvest indigo plants in the gardens belonging to the Gunungpati 03 farmer group guided by the group leader accompanied by a team of devotees. The technique used is to prune the shoots using a knife. 


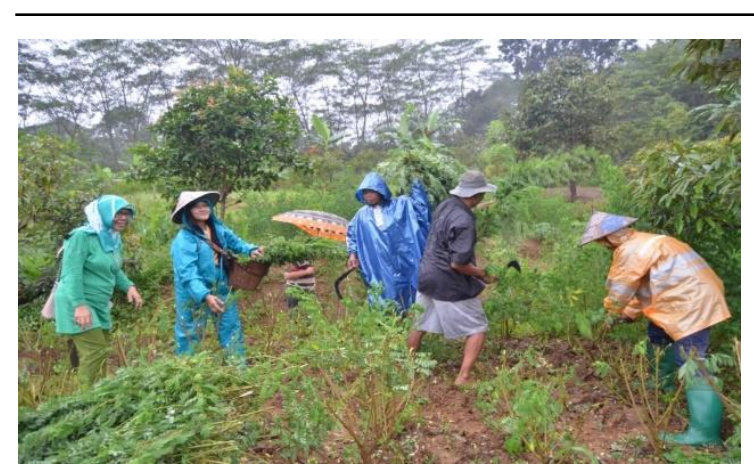

Figure 5. Indigofera Harvesting

The purpose of this method is the plants that have been cut off can grow back, so that one plant can be harvested up to 3 times. This activity was attended by 18 group members who were quite enthusiastic to join in indigo gardens and practice harvesting directly despite the rainy conditions.

\section{CONCLUSION}

Implementation of the activity produced 2 pieces of water reservoir products, compost made from dried leaves and livestock manure, indigofera seeds, indigofera plants ready for harvest in excrooked land. It is also known that members of farmer groups are motivated to grow quality indigo, but technological assistance is still needed especially in relation to seeding and fertilizing land before planting. The problem of water supply for watering in the dry season is already available in two places adjacent to the planting area. Paste making and crop harvest training are motivational activities related to product commercialization so as to increase household income.

Implanted land immediately planted, fodder and fertilization that determine the quality of indigo plants. It is recommended before planting given trichoderma mushrooms to cope with fungal disease attacks on plant roots.

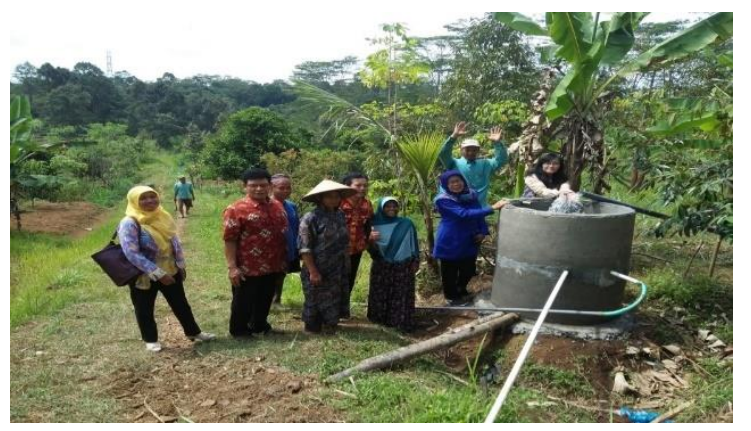

Figure 6. Water reservoir to maintenance indigofera.

\section{SUGGESTION}

Farmer groups that have understood the indigofera cultivation procedures can continue to run independently. The Service Team suggests farmer groups, service providers, or other research to see the productivity of indigofera in Gunungpati so that the effectiveness of this activity can be evaluated

\section{ACKNOWLEGEMENTS}

The authors would like to thank DRPM DIKTI Indonesia for the support of the funds that have been given. 


\section{REFERENCES}

Abidin, Z., Dyazra, A., Maharani, Z., \& ... (2020). Strategi Peningkatan Pertanian melalui Sosialisasi Pupuk Organik dan Budidaya Indigofera di Desa Sukawening, Kabupaten Bogor. Jurnal Pusat Inovasi ..., 2(5), 788-795. https://jurnal.ipb.ac.id/index.php/pim/ article/view/31728

Morip, W., Anis, S. D., Telleng, M. M., \& Sumolang, C. I. J. (2020). PENGARUH JARAK TANAM TERHADAP PRODUKTIVITAS INDIGOFERA (Indigofera zolingeriana) DI AREAL TERBUKA. Zootec, 40(2), 714-723. https://ejournal.unsrat.ac.id/index.php/ zootek/article/view/30176

Muzayyinah, M. (2014). Indigofera: “Kini dan Nanti." Bioedukasi: Jurnal Pendidikan Biologi, 7(2), 23. https://doi.org/10.20961/bioedukasiuns.v7i2.2932

Ranti, M. A. D., Suryani, N. N., \& Budiasa, I. K. M. (2019). Pengaruh Pemberian Kadar Air Berbeda terhadap Pertumbuhan dan Produksi Hijauan Tanaman Indigofera Zollingeriana. Peternakan Tropika Journal of Tropical Animal Science, 537-548. https://simdos.unud.ac.id/uploads/file_ penelitian_1_dir/80a62e1b18443e312 ea393947017b283.pdf
Rosadi, K., Abdullah, L., \& ... (2018). Evaluasi Peforma Benih Indigofera zollingeriana dari tanaman berbeda umur. Buletin Ilmu Makanan ..., 105(1), 1-10. http://journal.ipb.ac.id/index.php/bulm ater/article/view/19614

Setiati, N., Retnoningsih, A., \& Dewi, N. K. (2020). Pelatihan Kerajinan Eceng Gondok di Kecamatan Banyubiru untuk Menumbuhkan Wirausaha Baru. Journal of Dedicators Community, $4(1), \quad 1-11$. https://doi.org/10.34001/jdc.v4i1.972

Sindhu, P. V., Kanakamany, M. T., \& Beena, C. (2016). Effect of organic manures and biofertilisers on herbage yield, quality and soil nutrient balance in Indigofera tinctoria cultivation. Journal of Tropical Agriculture, 54(1), $16-20$.

Telleng, M., Wiryawan, K. G., Karti, P. D. M. H., Permana, I. G., \& Abdullah, L. (2016). Forage production and nutrient composition of different sorghum varieties cultivated with indigofera in intercropping system. Media Peternakan, 39(3), 203-209. https://doi.org/10.5398/medpet.2016.3 9.3.203

Theresia, M., Budiastuti, S., Pujiasmanto, B., Sulistyo, T. D., Ike, A., Agroteknologi, P. S., Pertanian, F., 
Maret, U. S., Agronomi, P. M.,

Pertanian, F., \& Maret, U. S. (2020).

Pemanfaatan Limbah Ekstraksi

Indigofera tinctoria L . sebagai Pupuk

Organik pada Usaha Batik Pewarna

Alami di Sukoharjo. PRIMA: Journal

of Community Empowering and

Services, 4(2), 109-119. 